\title{
Effect of Cooperative Make a Match Learning Model on Student's Learning Outcomes on Electrolyte and Non-Electrolyte Solutions Topics
}

\author{
Eska Perdanawati Kahar Putri \\ Universitas Tadulako \\ Palu, Sulawesi Tengah \\ eskakputri@gmail.com \\ Muslimah \\ Universitas Tadulako \\ Palu, Sulawesi Tengah \\ muslimahmuche43@gmail.com
}

\section{Ratman}

Universitas Tadulako

Palu, Sulawesi Tengah

ratmanut@gmail.com

\author{
Kasmudin Mustapa \\ Universitas Tadulako \\ Palu, Sulawesi Tengah \\ mumutep@gmail.com \\ Abdul Gani \\ LPMP \\ Palu, Sulawesi Tengah \\ ganiabdul13@yahoo.co.id
}

\begin{abstract}
The success of a learning process is determined by the teacher's role in developing the method's used. The cooperative make a match learning model or a pair performed by providing opportunities for students to find a partner for question and answer cards. This study aimed to investigate the effect of the cooperative make a match learning model towards student's learning outcomes in the electrolyte and non-electrolyte solutions topics. This research was a quasi-experimental design with nonrandomized pretest-posttest control group design with class XA was as an experimental group $(n=21)$ and class $X B$ was as a control group $(n=18)$. The data testing of student learning outcomes used t-test statistical analysis of the two parties with the prerequisite test: test for normality and homogeneity of a written test that was given after learning (post-test). The results of the data analysis for experiment class were $\left(X_{1}\right) \mathrm{M}=70.5$ with $\mathrm{SD}=$ 9.6, and the control class $\left(X_{2}\right) M=66.5$ with $S D=6,4$. Based on the results of testing hypotheses on two parties, it was obtained that $-t_{\text {tabel}},\left\langle t_{\text {calculation }}\right\rangle+t_{\text {table }}-2.042<7,45>+2.042$ with $\alpha=0.05$ and $\mathrm{df}=37$, then $\mathrm{H}_{0}$ was rejected and $\mathrm{H}_{\mathrm{a}}$ was accepted. It can be concluded that there is the effect of cooperative make a match learning model on student's learning outcomes in the electrolyte and non-electrolyte solutions topic in class X Madrasah Aliya DDI Lonja, where the results of students in the experimental class are higher than in the control class.
\end{abstract}

Keywords-Cooperative Learning Model, Model Make a Match, Electrolyte and Non-Electrolyte Solution, Students' Learning Outcomes

\section{INTRODUCTION}

Education has a strategic role in improving the quality of human resources and efforts to realize the ideals of the nation which is Indonesia in realizing common prosperity and intellectual life of the nation. Government formulated the Law of the Republic of Indonesia No. 20, 2003 Article 1 on National Education System which explains that "Education is a conscious and deliberate effort to create an atmosphere of learning and the learning process so that learners are actively developing the potential for him to have the spiritual power of religion, self-control, personality, intelligence, noble character, as well as the necessary skills themselves, society, nation, and state." [1]. The quality of education in Indonesia is still low, as evidenced by the results of the national exams (UN) were achieved by students from year to year. As for the things that affect the poor quality of education among others, the low quality of human resources, the learning process has not improved optimally, the lack of availability of facilities and infrastructure of learning. One effort that can be done to improve the quality of education is to improve the learning process. The learning process can be accomplished if the components in it are intertwined and together form a unity to achieve one goal. The components are structured and organized intertwined in the learning process are the teachers, students, curriculum and learning materials [2].

The success of any learning process is determined by the teacher's role in developing the methods used. The role of the teacher, in this case, is how the teachers' creativity in designing effective teaching and learning process, the learning process to develop methods with an emphasis on active participation of students in the classroom. The use of student-centered learning pattern would be expected to create conditions conducive to encourage students to be motivated to take active learning activities. Reality has shown that the achievement of an efficient learning process, not only with methods that are centered on the teacher or one-way communication but must also learn methods that are multi-directional or student- 
centered learning. If this does not work together, it will affect the quality of education, where it become low. In 2013 demanding curriculum and learning activities so that the student-centered teaching approaches require the use of strategies, methods, and techniques in accordance with the approach to involve active student participation in the learning process [3].

The results of the interview on the subject teachers of chemistry at Madrasah Aliya DDI Lonja, there was a students' problems in the learning process, especially in the subjects of chemistry. The teacher's interaction was lack with students for example students was more silent and less attention. The learning occured only applies in one direction. The learning method used in DDI Madrasah Aliya Lonja still use the lecture method, the method is valid only in one direction so as to make students become bored.

In the beginning of the second half of the 20th-century, the cooperative learning model has been evolving towards studentcentered. The cooperative learning generally consists of learning methods which teachers organize students into small groups, then work together to help each other achieve a shared learning [4]. The cooperative learning model can improve student learning outcomes for students will have more opportunities to help each other, exchange of resources needed, effective communication, and mutual influence. The cooperative learning model can improve the students' learning outcomes. Besides, students will have more opportunities to help each other, exchange of resources needed, effective communication, and mutual influence [5]. In the cooperative learning model, every person searches for a solution or performs a task that is important to him/her and to every other group member. This method improves results in knowledge areas as well as enhancing cognitive, social, emotional and motivational processes [6]. Therefore, it is assumed that the cooperative learning has a positive effect on students' cognitive, emotional and social skills, such as promoting higher achievement, greater use of higher level critical reasoning competencies and strategies, higher self-esteem, and greater collaborative skills and attitudes necessary for working effectively with others. However, the literature includes some studies reporting no significant effect on learning [7]. Cooperative learning is the instructional use of small groups so that students work together to maximize their own and each other's learning [8]. While researchers generally agree that cooperative learning can have a positive effect on student achievement, there remains a controversy about why and how various cooperative learning methods affect achievement and, most importantly, under what conditions cooperative learning has these effects [9]. Learning groups not only help students to interact with each other but can indirectly foster alternative ideas, as well as well as result in a problem solving through discussion [10].

In other research, the state of the class, as well as methods of teaching and learning, should be made more enjoyable so that students can interact with each other. Necessary models and more innovative teaching methods so as to make students more active and vibrant. The cooperative make a match learning model chosen in this study because it can create a more pleasant learning atmosphere where students are more active and interact with each other with their classmates. The result of this study showed an average score of teacher's skill in the cycle I was 3,5 with the excellent category, the cycle II was 3,7 with excellent category and the cycle III was 3,9 with excellent category too. The average of student activity in cycle I was 3,0 with the very good category, cycle II was 3,7 with very good category and the last in cycle III was 3,8 with very good category too. The exhaustiveness student learning in the initial condition only 2 from 48 students who achieve KKM (65). The average of process social learning which obtained by applying cooperative learning model of type Make A Match cycle I was 62,27 and 26 from 48 students experiencing learning exhaustiveness with percentage $54,16 \%$. In cycle II was 71,46 and 36 from 48 students had studied with the percentage of completeness $75 \%$. In cycle III was 79,90 and 41 from 48 students had studied with the thoroughness percentage $85,41 \%$ [11].

Results of research through observation of students' learning motivation towards 30 it can be seen that student motivation is still low in the first cycle to-one meetings with an average of $56.8 \%$ and in the 2 nd meeting increased to $63.3 \%$ and the second cycle of meeting to- 1 increased to $74.3 \%$ subsequent to the meeting of 2 increased to $82 \%$. Thus it can be said that the students' motivation on the material already is in the excellent cooperative. Then, from the results of a questionnaire given to 30 students, the first cycle showed a total of 18 students $(60 \%)$ is classified as a category of students who are motivated. In the second cycle showed as many as 28 students $(93.3 \%)$ is classified as a category of students motivated. Thus the use of a model of make a match can increase students' motivation fourth grade [12].

Make a match learning model is demand student to find the problem and answer card pairs, so that the application of make a match learning model can improve student learning outcomes. Chemical topics selected to implement cooperative make a match learning model of this research is electrolytes and nonelectrolytes solutions. Electrolyte and nonelectrolyte solutions topics selected for the learning done, the teacher simply explained while students just listen and imagine what the teacher explained other than that in practice also not in the form of experimentation, learning in this form in which students will be given a practice on electrolyte and nonelectrolyte solutions topics resulting in a more active student learning. The electrolyte and non-electrolyte solutions topics are fun when the learning is done in the form of experiments. One other factor is the absence of the cause to the school chemistry lab. Researchers hope that the students can understand the electrolyte and non-electrolyte solutions topics are meaningful and more fun with cooperative make a match learning model, so it is necessary to study titled "Effects of cooperative make a match learning model on student's learning outcomes on electrolyte and non-electrolytes solutions topics in class X Madrasah Aliya DDI Lonja".

\section{METHOD}

Type of research includes the type of quasi-experimental study using two groups: the experimental group was given treatment with cooperative learning model type make a match and a control group that was not given cooperative learning 
model make a match but using conventional learning models. The study design used in the study was the design of the control group using a pretest and post-test (non-randomized pretest-posttest control group design) This design is a design belonging to a quasi-experimental (quasi-experimental research) where the design of the selection group subjects did not do with random (random), for example, experiments in a particular class with students who have been there or as their [13].

This research was conducted at DDI Madrasah Aliya Lonja, Sulawesi Tengah, Indonesia, in the 2016/2017 academic year. The population in this study were all students of class $\mathrm{X}$ in DDI Madrasah Aliya Lonja that registered in the 2016/2017 academic year (39 students).Grade result of students in class $\mathrm{XA}$ and $\mathrm{XB}$ was relatively same but the level of completeness of students in class XB were better than students of class XA. So that, the design of experiment was class XA as experimnet class and class XB as the control class with the number of students 21 and 18 respectevily. Sampling technique was conducted by sampling saturated where this sampling technique when all members of the population used as a sample [14].

\section{RESULT AND DISCUSSION}

\section{A. Testing Requirements Analysis}

TABLE I. NORMALITY TEST

\begin{tabular}{|c|c|c|}
\hline Analysis & Experiment & Control \\
\hline $\mathrm{n}$ & 21 & 18 \\
\hline Mean & 43 & 52 \\
\hline $\mathrm{Sd}$ & 9.6 & 6.4 \\
\hline$\chi_{\text {tabel }}^{2}$ & 5.99 & 5.99 \\
\hline$\chi_{\text {calculation }}^{2}$ & 4.10 & 2.73 \\
\hline
\end{tabular}

TABLE II. HOMOGENEITY TEST

\begin{tabular}{|c|c|c|c|c|}
\hline Score & F $_{\text {table }}$ & df $_{\mathbf{1}}$ & $\mathbf{d f}_{\mathbf{2}}$ & $\mathbf{F}_{\text {calculation }}$ \\
\hline Posttest & 2.18 & 1 & 37 & 1.5 \\
\hline
\end{tabular}

Normality and homogeneity tests were done after the data obtained through post-test learning outcomes. This test was a prerequisite test. For the statistic test was used " $t$ " test in this case the two parties. Based on the normality test and achievement test for the experimental class values obtained $\chi_{\text {calculation }}^{2} \chi_{\text {table }}^{2}$ was $4.10<5.99$, and the normality of the data to the control class $\chi_{\text {calculation }}^{2} \chi_{\text {table }}^{2}$ was $2.73<5.99$. The result of the experimental class was normally distributed data. The data obtained has spread evenly between student learning outcomes were low, medium, and high. Based on test data homogeneity test study results value of $\mathrm{F}_{\text {calculation }}<\mathrm{F}_{\text {table }}$ where $1,5<2.18$ with $\alpha=0.05$, so it can be concluded that the data post-test for the control class and experimental class was homogeneous.

\section{B. Hypothesis Test}

TABLE III. T-TEST

\begin{tabular}{|c|c|c|}
\hline Analysis & Experiment & Control \\
\hline $\mathrm{N}$ & 21 & 18 \\
\hline$\overline{\boldsymbol{X}}_{1}$ & 70.5 & 66.5 \\
\hline$\overline{\boldsymbol{X}}_{2}$ & 93.5 & 42.1 \\
\hline $\mathrm{Df}$ & & 37 \\
\hline $\mathrm{t}_{\text {table }}$ & \multicolumn{2}{|c|}{2.042} \\
\hline $\mathrm{t}_{\text {calculation }}$ & \multicolumn{2}{|c|}{} \\
\hline
\end{tabular}

Results of statistical hypothesis testing to test ' $\mathrm{t}$ ' twoparty testing criteria is if $-t_{\text {table }} \leq t_{\text {calculation }} \leq+t_{\text {table }}$ then $H_{0}$ is accepted and $H_{a}$ rejected at $\alpha=0.05$ with $\mathrm{df}=37$. Based on the results obtained $-\mathrm{t}_{\text {table }}\left\langle\mathrm{t}_{\text {calculation }}\right\rangle+\mathrm{t}_{\text {table }},(-2,042<7,45\rangle$ $+2,042)$, then $\mathrm{H}_{0}$ was rejected and $\mathrm{H}_{\mathrm{a}}$ was accepted the conclusion that there are significant cooperative learning model make a match against student learning outcomes in an electrolyte solution material and nonelectrolytes in class $\mathrm{X}$ Madrasah Aliya DDI Lonja.

\section{DISCUSSION}

Teaching-learning process by using cooperative model types make a match was divided the students into three groups and implement the learning process according to RPP. In the end of the lesson or meeting conducted tests of student learning outcomes (posttest) with the aim to determine the effect of cooperative learning model make a match. Posttest resulted in the experimental class for the lowest score of 43 and the control class 52, for the highest scores in the experimental class was 86 and the class control was 76 while the average score on the post-test value experimental class of 70.5 with a standard deviation of 9.8 and control classes 66.5 with a standard deviation of 6.4. This suggests that the study results obtained in the experimental class were higher than the control class so that it proved that there is the influence of cooperative learning model make a match the learning outcomes of students in the experimental class.

Based on the hypothesis test results, showing that the cooperative learning model makes a match on material nonelectrolyte solution and electrolytes provide higher learning outcomes compared to conventional learning models lecture method. This is because the type of cooperative make a match learning model has the advantage of making the students be able to participate together with classmates to make learning more fun, but it also presented learning materials will attract more students. This is also evidenced by [1] in their research that concluded that cooperative makes a match learning model more effective in improving student learning outcomes when compared with conventional learning model. Learning by using cooperative learning model make a match is one of the good efforts made in the learning process chemistry especially in the electrolyte and non-electrolyte solutions topics because the models and methods of learning of students play an active role in the learning process because students are required to find a partner the right to question and answer through the cards that have been dealt [1]. 
Based on the results obtained, it showed that the first meeting of the student has not cooperated with the group, but students have already seen more daring provides the questions and responses to problems to the researchers, this is indicated when students do experiments on the electrolyte and nonelectrolyte solution topics. At the time of the game make a match the students with the orderly search for a card answers and questions, after finding each partner then performed the assessment by the assessment team, at the time of the assessment of each pair are scrambling to precede each other in order to become the fastest to get to the assessment team, commotion but precisely therein lies the effectiveness of students because each has found the answer that wants to be the fastest. At the second meeting of the students have started to work together in a group, it is seen when students give each other feedback, rebuttals, and questions to other groups. While the control class learning is done using conventional learning model where in this case the teacher fully provides information and knowledge to the students, the active role of the students just listen and gain a direct result of the task or problem of teachers. Students receive a verbal narrative and passive, ie, accept what is described by teachers without doing as much as possible [15].

Some things that become obstacles in the implementation of cooperative learning model make a match, the teachers are required to be able to master classes and be able to control the noise of students in the learning process, especially when groups of cardholders questions and answers to each other looking for a partner who causes trouble in class, as well as at the time of the student group that has fought to find other questions and answers addressing cards to the assessment team to be the fastest. However, researchers took the initiative to reduce the noise in the classroom with how to position these groups U-shaped and seek group cardholder question and answer cards lined up facing each other, then ordered the students to look for a partner that is aligned in front of them in advance, so that the effectiveness of the group became more as well as to reduce noise. Methods make a match also requires restrictions on a good time so that students do not play during the learning takes place and this can be reduced to provide a preliminary understanding to the students as well as strict control on the use of methods make a match, so the cooperative learning model make a match provide opportunities for students to more actively participate in various strategy and the way he believes in accordance with the ability to solve problems. It is expected student learning outcomes can develop optimally. This became the core of the cooperative learning model make a match is learning interactively build and educational activities by providing the opportunity for students to address the problem through various strategies.

\section{CONCLUSION}

Based on the analysis of research data, it can be concluded that there are effects of cooperative make a match learning model on student's learning outcomes on electrolyte and nonelectrolytes solutions topics in class X Madrasah Aliya DDI
Lonja, it also can be seen from the results of hypothesis testing by using t-test two-tailed at significant level, $\alpha=0.05, \mathrm{df}=\mathrm{n}_{1}+$ $\mathrm{n}_{2}-2$, obtained $-2.042<7.45>+2.042$. This shows that the cooperative makes a match learning model has better results than the control class that uses the conventional learning model.

\section{ACKNOWLEDGMENT}

Thanks to the motivation and support from various people, especially Prof. Daud and friends in Science Education Doctoral Studies Program which have provided science, guidance, motivation, invaluable advice, as well as the time for the author since the preparation of this article, the authors say many thanks.

\section{REFERENCES}

[1] N. Astika and N. M. Ayu Nyoman, "Efektivitas Model Pembelajaran Kooperatif Tipe Make a-Match Terhadap Hasil Belajar Siswa," J. Penelit. Pembelajaran Fis., vol. 3, no. 2, pp. 110-117, 2012.

[2] Aunurrahman, Belajar dan Pembelajaran. Bandung: Alfabeta, 2009

[3] E. Durukan, "Effects of cooperative integrated reading and composition (CIRC) technique on reading-writing skills," Educ. Res. Rev., vol. 6, no. 1, pp. 102-109, 2011.

[4] Harianto and M. Suyono, Belajar dan Pembelajaran. Bandung: PT Remaja Rosdakarya, 2012.

[5] V. D. Tran, "The Effects of Cooperative Learning on the Academic Achievement and Knowledge Retention,” Int. J. High. Educ., vol. 3, no. 2, pp. 131-140, 2014.

[6] A. R. Vrhovec, "Forms of Cooperative Learning in Language Teaching in Slovenian Language Classes at the Primary School Level," CEPS J. Cent. Educ. Policy Stud. J., vol. 5, no. 3, pp. 129-181, 2015.

[7] H. Chatila and F. Al Husseiny, "Effect of Cooperative Learning Strategy o n Students 'Acquisition and Practice of Scientific Skills in Biology," J. Educ. Sci. Environ. Heal., vol. 3, no. 1, pp. 88-99, 2017.

[8] D. W. Johnson and R. T. Johnson, "Cooperative learning in 21st century," An. Psicol., vol. 30, no. 3, pp. 841-851, 2014.

[9] R. E. Slavin, "Cooperative Learning and Academic Achievement: Why Does Groupwork Work?," An. Psicol., vol. 30, no. 3, pp. 785-791, 2014.

[10] N. N. Pandey and K. Kishore, "Effect of Cooperative Learning on Cognitive Achievement in Science," J. Sci. Math. Educ. S.E Asia, vol. 26, no. 2, pp. 52-60.

[11] A. Febriana, "Application of Cooperative Learning Model Type Make a Match to Enhance Quality of Learning Social Studies in Elementary School Students in Grade V Kalibanteng Kidul 01 Semarang," J. Kependidikan Dasar, vol. 1, no. 2, pp. 151-161, 2011.

[12] Y. Sijabat, "Meningkatkan Motivasi Belajar Siswa dengan Model Pembelajaran Kooperatif Tipe Make a Match pada Mata Pelajaran IPS di Kelas IV SD,” Elem. Sch. J. PGSD FIP UNIMED, vol. 1, no. 1, pp. 45-49, 2013.

[13] Sukardi, Metodologi Penelitian Pendidikan. Jakarta: PT Bumi Aksara, 2008 .

[14] Sugiono, Statistika untuk Penelitian. Bandung: Alfabeta, 2010.

[15] R. dan S. Artawa, "Pengaruh Model Pembelajaran Kooperatif Tipe Make A-Match Terhadap Prestasi Belajar Matematika Siswa Kelas V SD Di Gugus 1 Kecamatan Selat,” Mimb. PGSD, vol. 2, no. 1, pp. 3641, 2012. 